\title{
シナリオ地震による日本全国の地震危険度評価 \\ EVALUATION OF SEISMIC HAZARD DUE TO SCENARIO EARTHQUAKES IN OVERALL JAPAN
}

\author{
宇賀田 健* \\ Takeshi UGATA
}

\begin{abstract}
Scenario earthquakes are significant for not only evaluation of seismic loss in large urban areas, but also pricing of insurance linked securities for earthquake risk. This paper combines active fault data and historical seismic records to prepare the seismic sources for scenario earthquakes with their occurrence interval. The seismic sources for randomly distributed intraplate earthquakes without surface faults are also prepared so that they can be treated as scenario earthquakes. Using these seismic sources, I evaluate a maximum credible acceleration map in overall Japan due to scenario earthquakes.
\end{abstract}

\author{
keywords : Scenario earthquakes, Seismic hazard, Intraplate earthquakes without surface faults, Active faults, \\ Earthquakes along subduction zone, Occurrence interval \\ シナリオ地震, 地震危険度, 表層断層を伴わない地款内地震, 活断層, 海溝付近の地震, 発生周期
}

\section{1.はじめに}

建物や構造物の地震リスクを評価することは，地震被害想定を行 う国や自治体, あるいは電力, 水道等のライフラインを管理する事 業者にとって重要である。さらに近年では，資金の調達あるいはリ スクの分散という目的から，建物あるいは地震リスクを証券化する という動きが世界的に広まってきているのに伴い ${ }^{1)}$, 建物の所有者, 損害保険業者および投資家にとっても, 経営戦略あるいは投資戦略 において地震リスクを評価することの位置づけが高まってきている。 地震リスクを評価するためには，想定される地震の規模のみなら ず，その発生確率も同時に評価される必要がある。すなわち，いく ら予想される地震の規模が大きくても，その発生確率がほとんど無 視できるのであれば，地震リスクは小さくなる。

予想される地震動の特性とその発生確率との関係, 寸なわち地震 危険度を評価する手段として, Cornel1 ${ }^{2)}$ の方法が広く用いられてきた。 しかしながら, Cornell の方法は起こりうるすべての地震を考虑する ため，個々の地震が地震危険度に与える影響を把握し難い。広域的 な地震防災対策，あるいは点在する複数の建物を一括して証券化す る場合には，地震によって同時に発生する地震動の地域分布を知る 必要があるため, むしろ「現実的に起こり得るものの中で最悪の被 害をもたらす地震(シナリオ地震)」がいつ, どこで, どの程度の規模 で発生するかを明らかにし，それに対して防災対策を講じる，ある いはリスク指標(地震リスク証券において，元利金没収の基淮となる 事象) ${ }^{1)}$ を設定する方が一般に理解され易く有効であると考えられる。 このように, シナリオ地震による地震危険度を評価するためには, いつ, どこで, どの程度の規模で地震が発生するかを特定する必要 がある。Cornell の方法でも，活断層や沈み込みによる地震について は，これらの条件を特定することができ，これまでにも，これらの
地震をシナリオ地震として取り扱った地震危険度評価がいくつか行 われている ${ }^{3,4)}$ 。しかしながら，これらの震源から離れた地域では， 断層としては地表面に表れてはいないものの, 建物および構造物の 直下で発生する恐れのある地殼内地震もシナリオ地震となり得る。

Kawasumi $^{5}$ は過去に発生した地震による震度を, 緯度経度を各半 度に区切ったメッシュごとに統計処理することにより地震危険度を 評価している。この方法であれば, 断層として地表面に表れない地 震に対しても，過去に発生した地震の震源位置と規模さえ分かれば 地震危険度を評価することができるが，過去に一度も地震が記録さ れていない地点では将来的にも地震が発生しないことになる。それ に対して, Cornell の方法, あるいは文献 6 で示されている「確率論 的想定地震」では, 地震活動度が一定と見なせる「地震域」を想定 し，その中では Gutenberg-Richter 式(以下，G-R 式と称す)で表される $b$ 值モデルに基づき空間的にランダムに地震が発生すると仮定して いる。この方法によれば, たまたま過去に一度も地震が記録されて いない地点においても将来地震が発生する可能性を評価することが できるが, 想定している地震域の大きさが複数の都道府県を含む程 度に広いため, 直下地震によって同時に発生する地震動の地域分布 を把握し難く，このままの形ではシナリオ地震としては用いにくい。 そこで, 本論文では, 断層として地表面に表れない地震に対して, 上述の地震域と同様に, $b$ 值モデルに基づき空間的にランダムに発生 すると仮定するものの, その地震域を細かくすることにより,いつ, どこで, どの程度の規模で発生するかを特定する手法について示し た。また，それ以外の地震についても，日本全国を対象にして，シ ナリオ地震となり得る震源データとして整備するとともに, それら を用いて，シナリオ地震による地震危険度評価手法の基本的な考え 方を提示した。

*大成建設侏原子力設計グループ 工修 Nuclear Facilities Planning \& Design Group, Taisei Co., M. Eng. 


\section{2. シナリオ地震となり得る震源データの作成}

\section{1 震源データの種類と設定する諸元}

シナリオ地震となり得る震源データは, 文献 7 を参考にして, 以 下の 5 種類に分類する。

（1）地表面に断層として表れない中規模な地殼内地震

(2) 活断層による大規模な地殼内地震

(3) 活断層と関連しない大規模な地殼内地震

(4) 大規模な海溝付近の地震

(5) 日本海東縁海域の大規模な地震

地款内地震については，M6.5〜M6.8 を境にして，それ以下の規模 の地震は厚さ $15 \sim 20 \mathrm{~km}$ 程度の地震発生層内でとどまり, 断層とし て地表面に露出しないことが多いことから ${ }^{8,9)}$, ここでは, M6.8 を境 にして，それ以上の規模の地震を地表面に表れた活断層による大規 模地震, それより小さい規模の地震は地表面に断層として表れない 深さ $20 \mathrm{~km}$ 以浅の中規模地震として取り扱った。

また, 樑さ $70 \mathrm{~km}$ 以深のやや深発地震に対しては, 深さが $70 \mathrm{~km}$ $150 \mathrm{~km}$ で M7.5 以上であれば比較的規模の大きな被害地震になり得 るという指摘がある ${ }^{10)}$ 。そこで，これらの条件を満足するやや梁発 地震もシナリオ地震となり得る震源データとして整備するが, 震源 深さが特定し易い 1885 年以降でこれらの条件に満足するものは, 震 源位置から判断していずれも海溝付近の地震に分類できると考えて, ここでは, 海溝付近の地震の一部として取り扱った。

さらに, 上記以外にも深発地震, 海溝付近で M6.8 未満の中小規模 の地震があるが，いずれも大規模な地震被害をもたらさないと判断 されることからシナリオ地震となり得る震源データからは除外した。

これらの地震をシナリオ地震となり得る震源データとするために， (1)震源の位置(緯度, 経度, 深さ), (2)地震の規模(マグニチュード), (3)発生周期，を設定するとともに，地震発生の時間依存性を考慮す る地震に対しては，さらに(3)'発生周期のばらつき，(4)前回の地震発 生年，の各諸元を設定する。いずれの諸元も確定值としたが，地震 発生の時間依存性を有する地震に対してのみ，(3)の発生周期を確率 変数として取り扱った。

\section{2 具体的な震源データの設定}

2.1 節で示した(1)〜(4)までの諸元を以下に示す手法に従って具体 的に設定した。なお，日本全国を対象とした震源データを設定する ため, データの乏しいところでは発生周期の評価や断層面の設定に おいてかなり大胆な仮定を行っている。このような部分については, 別途個別に詳細な検討が行われることが望まれる。

（1）地表面に断層として表れない中規模な地殼内地震の震源データ

地表面に断層として表れない中規模な地殼内地震は，(1)式に示す G-R 式に従って, 空間的, 時間的にランダムに発生すると仮定する。

$\log N(M)=A-b \cdot M$

ここで, $N(M)$ はマグニチュード $M$ 以上の地震の発生頻度, $A$ お よび $b$ は係数である。ただし, シナリオ地震用の震源データとする ためには，その発生位置と規模を特定する必要があるので，評価の 分かり易さおよび簡便さから，全国を機械的にメッシュ分割して， そのひとつひとつのメッシュがそれぞれ震源データであるとした。

各メッシュの G-R 式は，そのメッシュが含まれる「地震域」のも のを用いる。地震域とは地震の活動度が一定と見なせ, G-R 式に従つ て地震が発生すると考えられる地域である。地震域の設定の仕方に

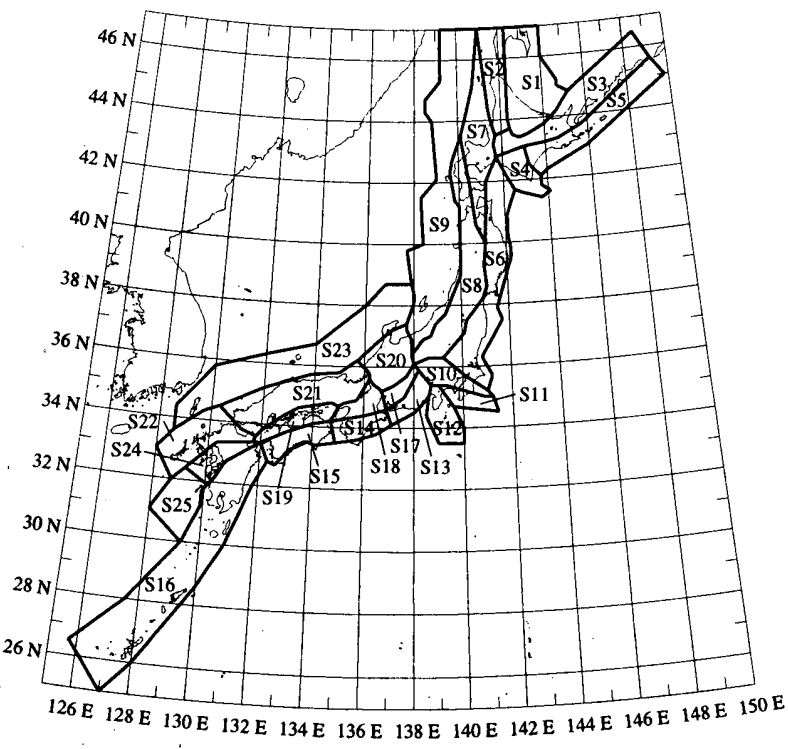

図 1 地表面に断層として表れない中規模な地殸内地震の

震源データ作成用の地震域

表 1 地表面に断層として表れない中規模な地款内地震の震源 データを設定するための各地震域の諸元

\begin{tabular}{|c|c|c|c|c|}
\hline 番号 & 地震活動域名 & $\begin{array}{l}\text { 震源 } \\
\text { 深さ } \\
(\mathbf{k m})\end{array}$ & $b$ 値 & $\begin{array}{l}\text { 単位面積当り } \\
\text { 年発生頻度 } \\
\text { (回/年 } / \mathrm{km}^{2} \text { ) }\end{array}$ \\
\hline S1 & 北海道北東部 & 10.0 & 0.54 & $4.38 \times 10^{-7}$ \\
\hline S2 & 北海道中部北側 & 16.7 & 1.34 & $1.78 \times 10^{-6}$ \\
\hline S3 & 千島弧内部 & 6.7 & 0.68 & $1.93 \times 10^{-6}$ \\
\hline S4 & 北海道中部南側 & 10.8 & 0.73 & $1.77 \times 10^{-5}$ \\
\hline S5 & 千島张外部 & 6.5 & 0.84 & $7.62 \times 10^{-6}$ \\
\hline S6 & 東北地方外帯 & 7.3 & 0.91 & $1.68 \times 10^{-5}$ \\
\hline S7 & 東北地方内帯陸域北側 & 5.0 & 0.85 & $3.55 \times 10^{-6}$ \\
\hline S8 & 東北地方内帯陸域南側 & 5.0 & 1.13 & $9.47 \times 10^{-6}$ \\
\hline S9 & 東北日本内帯海域 & 8.8 & 1.26 & $4.82 \times 10^{-6}$ \\
\hline$S 10$ & 関東北部 & 8.7 & 0.81 & $1.55 \times 10^{-5}$ \\
\hline S11 & 関東南部 & 9.1 & 0.73 & $1.36 \times 10^{-5}$ \\
\hline $\mathbf{S 1 2}$ & 伊豈半島 & 8.1 & 0.93 & $5.92 \times 10^{-5}$ \\
\hline $\mathbf{S 1 3}$ & 西南日本-琉球弧外带東端 & 6.5 & 0.83 & $1.69 \times 10^{-5}$ \\
\hline S14 & 西南日本-琉球弧外帯(紀伊半島) & 7.7 & 0.90 & $1.51 \times 10^{-5}$ \\
\hline S15 & 西南日本-琉球弧外帯(四国) & 8.0 & 1.69 & $1.06 \times 10^{-5}$ \\
\hline S16 & 西南日本-琉球弧外带(九州,南西諸島) & 6.3 & 0.93 & $7.79 \times 10^{-6}$ \\
\hline S17 & 西南日本内帯南部東端 & 10.0 & 1.03 & $1.20 \times 10^{-5}$ \\
\hline S18 & 西南日本内帯南部（紀伊半島北部） & 6.7 & 0.97 & $8.77 \times 10^{-6}$ \\
\hline S19 & 西南日本内带南部（瀬戸内海） & 11.7 & 0.97 & $4.60 \times 10^{-6}$ \\
\hline $\mathbf{S 2 0}$ & 西南日本内帯北部東端 & 5.0 & 0.83 & $1.16 \times 10^{-5}$ \\
\hline $\mathbf{S} 21$ & 西南日本内帯北部 (中国地方) & 7.9 & 0.98 & $1.20 \times 10^{-5}$ \\
\hline $\mathbf{S 2 2}$ & 西南日本内帶北部 (九州北部) & 3.3 & 1.18 & $2.02 \times 10^{-6}$ \\
\hline S23 & 西南日本内帯沿海部 & 9.1 & 0.81 & $6.90 \times 10^{-7}$ \\
\hline S24 & 中九州火山地域 & 5.0 & 1.09 & $2.30 \times 10^{-5}$ \\
\hline $\mathrm{S} 25$ & 沖縄トラフ北部 & 6.3 & 1.00 & $6.14 \times 10^{-6}$ \\
\hline
\end{tabular}

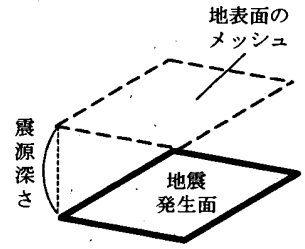

メッシュと同型で震源 深さが一定の面上で地

震が発生すると仮定

（1）地表面に断層が表れない 中規模な地款内地震
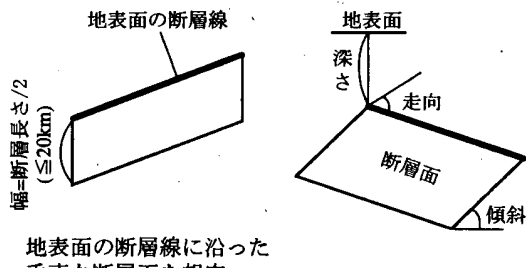
垂直な断層面を想定

(2) 活断層による 大規模な地殼内地震
(3) (1),(2)以外
図 2 各震源データの地震発生位置あるいは想定断層面 
ついてはいろいろな提案がなされているが，ここでは，萩原による 「実用的地体構造マップ」 ${ }^{11)}$ に基づき図 1 のように設定した。なお, 同マップに示されていない千島列島および南西諸島付近は, 過去の 地震の震源分布および海溝の位置を, また伊豆半島付近は過去の地 震の震源分布を参考にして分割した。ただし，M8クラスの地震が数 百年程度以下の頻度で発生する太平洋側海域については, シナリオ 地震としては海溝付近の地震が有意になるとして, ここではモデル 化していない。

また, 各地震域ごとの G-R 式は, その地域内に発生した過去の地 震データを用いて評価した。G-R 式を評価する際, その地域に発生 した全ての地震データを考慮しても良いが, 地殼内地震は必ずしも 同じ傾向で地震が発生しているわけではなく, M6.8 付近で地震発生 数の傾向が異なるという指摘 ${ }^{8)}$ もあり, 評価範囲以外のデータを用 いると評価範囲における地震規模別発生頻度を的確に表せない可能 性があると考え, ここでは, M5.0 から M6.7で, 震源梁さが $20 \mathrm{~km}$ 以浅のデータを用いた。また, 古文書から評価された歴史地震デー タは, M6.8 より小さいデータが少ないことから 1926 年以降(1999 年 11 月まで)の気象庁データを用いた。さらに,「地震は時間的にラン ダムに発生する」と仮定しているため, 本震との因果関係が強い前 震および余震記録と考えられるものは除去した。

以上の条件に適合した地震データを用いて評価した地震域ごとの 諸元を表 1 に示す。なお， G-R 式の $b$ 值は最尤法で近似した。この ように評価した地震域に基づき, 地表面に断層として表れない中規 模な地殸内地震の震源データを以下のように作成する。

(1)震源の位置

地震は, 図 2(1)に示されるように, メッシュと同型で震源梁さが 一定の「地震発生面」上で空間的にランダムに発生すると仮定する。 すなわち, 文献 6 で示されている「地震域」と同じ考え方であるが, その違いは, 震源データの大きさと, 次項(2)で示す地震規模の与え 方である。文献 6 では, 震源データの大きさは, 地震域とほぼ同程 度の広さを持ったものとして, 例えば図 1 程度の広さを有するもの として与えている。しかしながら, 震源データの大きさがこれだけ 広いと,これを直下地震の震源として取り扱っても, 直下地震によっ て同時に発生する地震動の地域分布は表現し難いと考えられる。そ こでここでは, 震源データ, 寸なわちメッシュの大きさがマグニ チュード $M$ に対応した断層面積 $S$ と同程度になるように設定するこ とにした。すなわち， $S$ とMの関係式 ${ }^{2)}$

$$
\log S\left(\mathrm{~km}^{2}\right)=M-4.07
$$

を用いると, 次項(2)に示す代表マグニチュードの最大值である M6.5 に対する断層面の面積が約 $270 \mathrm{~km}^{2}$ となることから,この大きさにほ ぼ等しい一辺約十数 $\mathrm{km}$ 四方のメッシュを想定することにした。具 体的には, 図 1 に示した地震域の範囲を緯度経度それぞれ 0.2 度ずつ 刻んでメッシュを作成した。その結果, 全国で 2924 個のメッシュを 考慮することになった。

(2)地震の規模

メッシュとして表された各震源データは，それを含む地震域の G-R 式に従ってさまざまな規模の地震を発生させることになるが, シナリオ地震となり得る震源データとしては, ある特定のマグニ チュードを設定する必要がある。そこで，ある範曲のマグニチュー ドに対してマグニチュードの代表值を与えることにした。ただし，
マグニチュードの範囲を設定する際には, 地震規模の違いが地震被 害に与える影響, および次項(3)で評価される発生周期の大きさとの バランスを考慮して設定する必要がある。すなわち，考慮するマグ ニチュードの範囲が小さすぎるとその範囲の地震が発生する確率が 極めて小さくなり，4 章で示す「現実的に起こりうる地震」ではなく なる可能性が大きくなる。逆に，大きすぎると，地震規模の違いが 地震被害に与える影響が無視できなくなってしまう。この問題につ いては, 今後の検討を待つことにして,ここでは, マグニチュード の範囲を 0.5 刻みと仮定して, M5.3〜M5.7 までを M5.5, M5.8〜M6.2 を M6.0，M6.3〜M6.7を M6.5 で代表させて評価することにした。 (3)発生周期

地震の発生周期は, 一年あたりの地震発生頻度の逆数として評価 する。マグニチュード $M$ から $M+\Delta M$ までの範囲の地震発生頻度は G-R 式から，次式で評価できる。

$$
N(M)-N(M+\Delta M)=10^{A-b \cdot M}-10^{A-b(M+\Delta M)}
$$

ここで, $A$ 值および $b$ 值は各メッシュに対する值であるが, $b$ 值は メッシュの中心が含まれる地震域の值そのものを用い, $A$ 值は各メッ シュの面積 $S_{M E S H}$ を考慮して次式で評価する。

$$
A=\log \left(S_{M E S H} \cdot v_{S}\right)+b \cdot M_{\min }
$$

ここで， $M_{\min }$ は考慮した地震の最低マグニチュード， $v_{S}$ はメッ シュの中心が含まれる地震域の $M_{\min }$ 以上の地震の単位面積当たり の年発生頻度である。

例として M6.0 に対する各メッシュの発生周期を図 3 に示す。

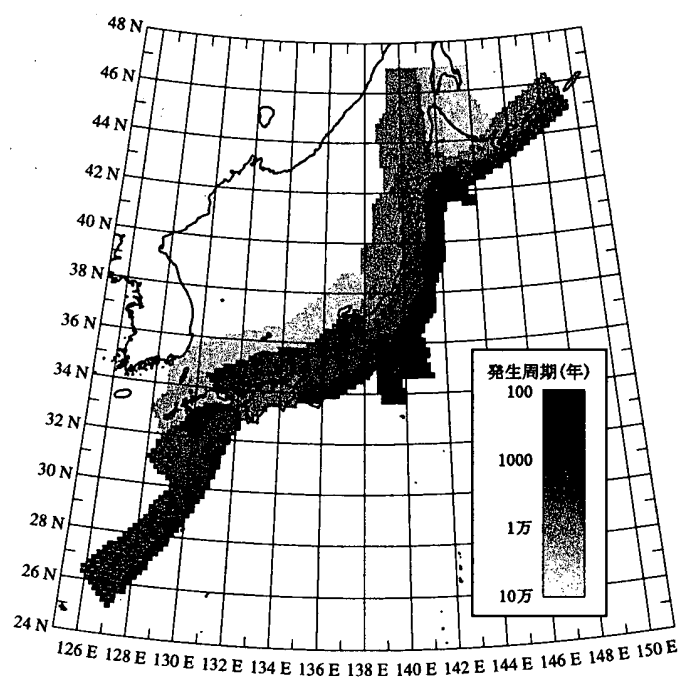

図 3 中規模な地壳内地震のメッシュごとの発生周期(M6.0)

\section{（2）活断層による大規模な地殼内地震の震源データ}

現在までに知られている活断層のうち，断層長さから想定される 地震の規模(下記(2)参照)が M6.8 以上のものを大規模な地款内地震の 震源データとして選定した。なお，断層のグルーピングおよびその 長さの設定については文献 17 を基本とし, 最新の調查結果である文 献 14〜16に記載されているものについてはそちらを優先した。 (1)震源の位置

図 2(2)に示すように，断層長さの半分の幅を持つ垂直な断層面と してモデル化した。ただし，地震発生層の厚さを考慮して，断層の 幅は $20 \mathrm{~km}$ を上限とした。 
断層の位置は活断層研究会「新編 日本の活断層」の図版 ${ }^{13)}$ を参考 にして設定した。場合によっては複数の断層が一塊になって地震を 引き起こすと想定されたり，極端に湾曲しているものもあったが， ここでは，簡単のために断層を一本の線分としてモデル化した。よ り詳細な検討を行う際には, 実際の断層線に近い形でモデル化する ことが考えられる。

\section{(2)地震の規模}

断層長さ $L$ から，(5)式に示す松田による式 ${ }^{18)}$ 加逆算する。

$\log L(\mathrm{~km})=0.6 M-2.9$

(3)発生周期の平均値とばらつき

各断層の発生周期は，断層が一回の地震でずれる距離(滑り 量) $d(\mathrm{~m})$ を平均変位速度 $s_{R}$ ( $\mathrm{m} /$ 年)で除することによって評価する。 一回の地震でずれる距離は(6)式に示す松田による式 ${ }^{18)}$ で評価する。 $\log d(\mathrm{~m})=0.6 M-4.0$

すなわち， $d$ は(5)および(6)式を介して断層長さ $L$ から評価される ことになる。両式とも経験式であるので，Lから $d$ を評価する際に 経験式を 2 回介することになるが，文献 8 によれば，両式とも M6.8 以上の地款内地震に対して適用性が高いことが確認されており，両 式から得られる $L-d$ 関係も過去の記録をよく表現できていた。

一方, 各断層の平均変位速度 $s_{R}$ は, 文献 13〜16 で具体的な值が 記されているものはその值, それ以外のものについては地震活動度 (A〜Cおよび記載なし)から評価した。なお, 平均変位速度は, 地震 活動度に対応する值 ${ }^{133}$ のように幅を持って与えられていたり，文献 によって異なる值が記載されている場合が多い。平均変位速度は卜 レンチ調査等から決定されるが，そこで得られた值は断層のごく一 部であるにすぎず，幅を持って与えられていたとしても，それらの 值が必ずしも上限値あるいは下限值を示しているとは言い難い。そ こで，幅として与えられている場合も含み，対象とした文献に記載 されている全ての値の中で最大のものおよび最小のものが，それぞ れ平均值十標準偏差および平均値一標準偏差に相当すると仮定した。

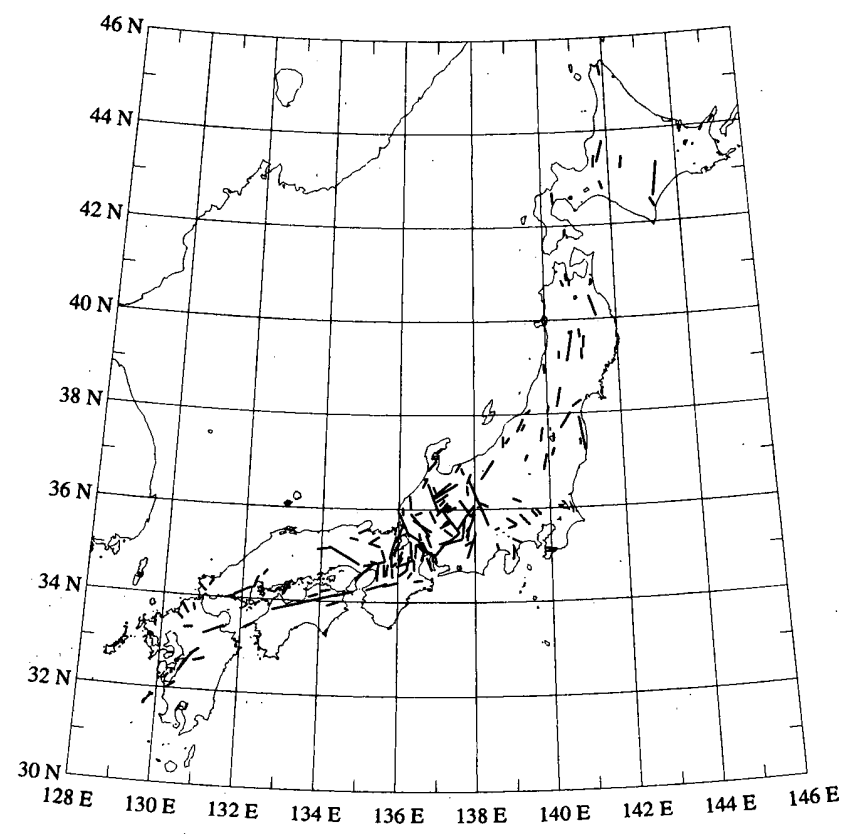

図 4 活断層による大規模な地款内地震の震源データ位置
ただし，平均変位速度がひとつの值しか与えられていない場合，あ るいは上述のように評価されたばらつきが非常に小さい場合には， 文献 19 を参考にして，変動係数として 0.2 を与えた。

(4)前回の地震発生年

前回の地震発生年は, トレンチ調査あるいはその断層が震源と考 えられる地震の発生年に基づき設定する。ただし，前回の地震発生 年についても幅をもって設定されていたり，まったく特定できない 場合が多い。文献 21 では，これらの場合でも, 前回からの地震の経 過時間を確率変数として取り扱ったり，経過時閒そのものを仮定し て前回の地震の発生年を評価しているが, ここでは, 前回の地震発 生年が特定できないもの，できたとしても発生周期と比較して合理 的な説明ができないものについては, 前回の地震発生年を設定せず, 地震はランダムに発生すると仮定して取り扱った。

以上の手法に従い設定した全国 165 本の震源データを図 4 に, 諸 元を表 2 に示す。なお， 表 2 には，前回の地震発生年を設定するに あたり用いた文献番号を備考欄に示している。

\section{（3）活断層と関連しない大規模な地殼内地震の震源データ}

M6.8 以上の地殸内地震であっても，必ずしも地表面に断層として の痕跡を残すとは限らず，(2)で選択した活断層とは関連のない地震 も過去において発生している。ただし, 過去の地震と断層の関連性 は，被覆層の影響や植生などのため困難な場合が多く、はっきりし ないものもあるが 8), ここでは, 文献 8 の表 2 に示された, 表層断 層と関連付けられた地殼内地震の中から, M6.8 以上で (2)で選択さ れた活断層と関連していないものをシナリオ地震用の震源データと して整備することにした。

なお, 文献 8 の表 2 は 1885 年以降の地震についてのみを対象とし ている。それ以前についても活断層と関連のない地震は発生してい るであろうが，それに関するデータがそしく, 活断層による地震と 二重に評価してしまう恐れがあるため，ここでは考虑しなかった。

具体的には表 3 に示す 6 個の地震を選択し, その震源位置を中心 とする断層面を設定し，それを震源データとした。このうち，1984 年長野県西部地震と 1900 年宮城県北部地震以外は, 文献 8 の表 2 に おいて断層と関連付けられているが，それが地震断層であったり， 設定した断層長さから評価された地震規模が M6.8 より小さく (2)で 選択されなかったものである。また, 1914 年桜島地震は桜島の噴火 に伴うもので, 文献8の表 2では断層と関連付けられていないが，(2) で, 文献 20 に従い鹿児島県西縁断層と関連付けているため,ここで は選択しなかった。

(1)震源の位置

震源は, 表 3 で示した地震の震源位置を中心とする断層面として 図 2(3)に示すように設定する。断層面は, 断層面積 $S$ とマグニチュー ド $M$ の関係を表す(2)式と，断層長さ $L$ と $M$ の関係を表す式 ${ }^{12)}$

$\log L(\mathrm{~km})=0.5 M-1.88$

から得られる長方形とした。ここで, $L$ と $M$ の関係式を(5)式ではな く(7)式としたのは, $S$ と $M$ の関係を表す(2)式が，(7)式と関連付けら れて設定されているからである。

また，断層面の走向および傾斜は，文献 12 に断層パラメータが示 されている地震についてはその值, それ以外については, その地震 の震源に近い断層と同じ走向で垂直な断層面を想定した。 
表 2 活断層による大規模な地壳内地震の震源データ諸元

\begin{tabular}{|c|c|c|c|c|c|c|c|c|c|c|c|c|}
\hline & & & & 発生) & & 前回のt & & & & 断層 & & 発生 \\
\hline 断層 & 断層名 & 長 $L$ & 規模 & 平均值 & 変動 & 発生的 & & 断層 & 断層名 & 長 $L$ & 規模 & 平均值 \\
\hline & & & & (年) & 係数 & 西暦(年) & 備考 & & & $(\mathrm{km})$ & & (年) \\
\hline 1 & \begin{tabular}{|l|} 
羅兒岳断層带 \\
\end{tabular} & 20 & 7.0 & 670 & 0.82 & - & - & 84 & 城端一上梨断層 & 15 & 6.8 & 12000 \\
\hline 2 & \begin{tabular}{|l|l} 
峰浜断層群 \\
\end{tabular} & 15 & 6.8 & 590 & 0.82 & - & - & 85 & 庄川断層带 & 80 & 8.0 & 12000 \\
\hline 3 & \begin{tabular}{|l} 
網走湖東方断層群 \\
\end{tabular} & 15 & 6.8 & 5400 & 0.20 & - & - & 86 & 福井平野菄緣断層带 & 30 & 7.3 & 16000 \\
\hline$\frac{3}{4}$ & 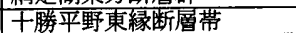 & 83 & 8.0 & 120000 & 0.96 & $=$ & - & 87 & 岮泉寺断層群 & 17 & 6.9 & 13000 \\
\hline 5 & 光地園断后 & 22 & 7.1 & 16000 & 0.60 & - & 二 & 88 & 喜食川上流断層带 & 28 & 7.2 & 7800 \\
\hline 6 & 富良野断層带 & 25 & 7.2 & 8400 & 0.60 & -5000 & $\mathrm{a}$ & 89 & 根尾谷断層带 & 67 & 7.9 & 11000 \\
\hline 7 & 幌延断層 & 23 & 7.1 & 71000 & 0.82 & - & - & 90 & 武儀川断屬 & 28 & 7.2 & 7800 \\
\hline 8 & 馬追丘陵西縁断層带 & 20 & 7.0 & 13000 & 0.82 & -1000 & $\mathrm{a}$ & 91 & 揖斐川断層帯 & 24 & 7.1 & 7300 \\
\hline 9 & 增单山地東縁断層带 & 44 & 7.6 & 11000 & 0.69 & - & - & 92 & 宝慶寺断層 & 18 & 6.9 & 13000 \\
\hline 10 & 当別断層 & 28 & 7.2 & 7800 & 0.82 & - & - & 93 & 池田山断層 & 16 & 6.8 & 1400 \\
\hline 11 & 折爪断層 & 50 & 7.7 & 14000 & 0.33 & -27000 & $\mathrm{~b}$ & 94 & 柳ヶ瀬断層带 & 56 & 7.7 & 11000 \\
\hline 12 & \begin{tabular}{|l|} 
双葉断層 \\
\end{tabular} & 70 & 7.9 & 14000 & 0.27 & 0 & $\mathrm{~b}$ & 95 & 関ヶ原断層带 & 27 & 7.2 & 1500 \\
\hline 13 & \begin{tabular}{|l} 
笂样森付近 \\
\end{tabular} & 15 & 6.8 & 5900 & 0.82 & - & $=$ & 96 & 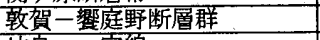 & 48 & 7.6 & 2400 \\
\hline 14 & 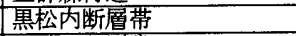 & 28 & 7.2 & 8300 & 0.71 & - & $=$ & 97 & 岐阜一二管線 & 32 & 7.3 & 820000 \\
\hline 15 & 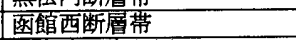 & 18 & 6.9 & 12000 & 0.89 & -6300 & $\mathrm{~b}$ & 98 & 加木屋断層 & 30 & 7.3 & 11000 \\
\hline 16 & 青森湾西岸断層 & 16 & 6.8 & 6100 & 0.82 & - & - & 99 & 高浜撓曲崖 & 21 & 7.0 & 9400 \\
\hline 17 & \begin{tabular}{|l} 
䢖軽山地西緣断層带 \\
\end{tabular} & 15 & 6.8 & 5400 & 0.20 & 1766 & $\mathrm{~b}$ & 100 & 津島断層群 & 31 & 7.3 & 11000 \\
\hline 18 & 花巻断層带 & 23 & 7.1 & 6500 & 0.20 & -4000 & $\mathrm{a}$ & 101 & 養老断層 & 31 & 7.3 & 730 \\
\hline 19 & 等石盆地西緣断層带 & 20 & 7.0 & 7000 & 0.75 & - & - & 102 & 焉老西䋎断層带 & 23 & 7.1 & 71000 \\
\hline 20 & 横手盆地東緑断層帝 & 70 & 7.9 & 2100 & 0.27 . & 1896 & b & 103 & 桑名断層群 & 20 & 7.0 & 990 \\
\hline 21 & 北上西断瞻带 & 23 & 7.1 & 9700 & 0.33 & - & $=$ & 104 & 鈴鹿東緣断層带 & 33 & 7.4 & 27000 \\
\hline 22 & 極盗寺－七曲腙断層 & 18 & 6.9 & 64000 & 0.82 & - & - & 105 & 布引山地東緣断層带 & 27 & 7.2 & 11000 \\
\hline 23 & 厓内平野秉緣断層带 & 22 & 7.1 & 7000 & 0.82 & 1894 & $\mathrm{c}$ & \begin{tabular}{|l|}
106 \\
\end{tabular} & 伊勢湾断着 & 32 & 7.3 & 3000 \\
\hline 24 & 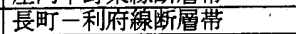 & 25 & 7.2 & 7700 & 0.75 & - & - & \begin{tabular}{|l|}
107 \\
\end{tabular} & 鈴鹿西麓断層带 & 47 & 7.6 & 18000 \\
\hline 25 & 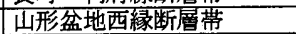 & 45 & 7.6 & 7200 & 0.20 & -2150 & $\mathrm{~b}$ & 108 & 鈴鹿坂下断層 & 15 & 6.8 & 5900 \\
\hline 26 & 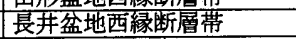 & 21 & 7.0 & 3900 & 0.60 & - & - & 109 & 頓宮断層 & 32 & 7.3 & 8200 \\
\hline 27 & 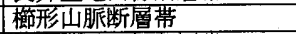 & 15 & 6.8 & 11000 & 0.20 & - & $=$ & 110 & 条津川断層带 & 30 & 7.3 & 8000 \\
\hline 28 & $\begin{array}{l}\text { 福島盆地西緣断層帯 } \\
\end{array}$ & 46 & 7.6 & 5200 & 0.69 & 1956 & $\bar{a}$ & 111 & 大鳥居断層 & 20 & 7.0 & 67000 \\
\hline 29 & |川析山断層 & 19 & 7.0 & 6600 & 0.82 & - & - & 112 & $\begin{array}{l}\text { 信楽断層带 } \\
\end{array}$ & 17 & 6.9 & 63000 \\
\hline 30 & $\begin{array}{l}\text { 江花－虫笠断層带 } \\
\end{array}$ & 18 & 6.9 & 640000 & 0.82 & - & $=$ & 113 & 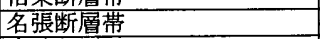 & 30 & 7.3 & 80000 \\
\hline 31 & 度会津盆地西緣断層带 & 35 & 7.4 & 3600 & 0.45 & 1611 & $a$ & 114 & 家城断層 & 16 & 6.8 & 610000 \\
\hline 32 & 月岡断層帯 & 37 & 7.4 & 3600 & 0.20 & -3240 & $\mathrm{~b}$ & 115 & 多気断層 & 20 & 7.0 & 67000 \\
\hline 33 & $\begin{array}{l}\text { 沼越峠断層 } \\
\end{array}$ & 16 & 6.8 & 6100 & 0.82 & - & - & 116 & 方断層 & 15 & 6.8 & 11000 \\
\hline 34 & 関谷断層 & 40 & 7.5 & 1500 & 0.62 & 1683 & $\mathrm{a}$ & 117 & 琵琶湖西岸断層带 & 40 & 7.5 & 4400 \\
\hline 35 & 桧枝岐西断層 & 15 & 6.8 & 59000 & 0.82 & - & 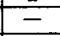 & 118 & 花折断層帯 & 54 & 7.7 & 49000 \\
\hline 36 & 霧ヶ峰断層群 & 20 & 7.0 & 1300 & 0.82 & - & - & 119 & 穻治断層帯 & 25 & 7.2 & 20000 \\
\hline 37 & 入内人断層 & 15 & 6.8 & 2200 & 0.45 & -1650 & $\mathrm{~b}$ & 120 & 和東谷断層 & 15 & 6.8 & 11000 \\
\hline 38 & 悠久山断層 & 15 & 6.8 & 2200 & 0.20 & - & - & 121 & 奈良盆地西断層群 & 25 & 7.2 & 15000 \\
\hline$\frac{30}{39}$ & 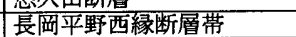 & $\frac{15}{25}$ & 7.2 & 3800 & 0.76 & 1961 & $\mathrm{a}$ & 122 & 尘駒断層带 & 30 & 7.3 & 15000 \\
\hline 40 & \begin{tabular}{|l|l|} 
\\
\end{tabular} & 60 & 7.8 & 5300 & 0.88 & 1854 & $\mathbf{a}$ & 123 & 有馬－高柣断層带 & 53 & 7.7 & 20000 \\
\hline 41 & 鶕川地清帯北断層 & 29 & 7.3 & 2900 & 0.20 & - & - & 124 & 十万辻断層 & 16 & 6.8 & 61000 \\
\hline 42 & 鹊川地湴带南断層 & 26 & 7.2 & 3400 & 0.33 & -2895 & b & 125 & 六甲断層带 & 47 & 7.6 & 9700 \\
\hline 43 & 平井一楖挽断層带 & 20 & 7.0 & 18000 & 0.72 & 1931 & $a$ & 126 & 奈良盆地東縁断層帯 & 22 & 7.1 & 8500 \\
\hline 44 & \begin{tabular}{|l} 
荒川断層 \\
\end{tabular} & 20 & 7.0 & 9200 & 0.33 & 1855 & $\mathrm{a}$ & \begin{tabular}{|l|}
127 \\
\end{tabular} & 大和川断層带 & 20 & 7.0 & 6700 \\
\hline 45 & 立川断層带 & 30 & 7.3 & 14000 & 0.71 & 450 & $\mathrm{~b}$ & 128 & 中央構造線和泉－金剛断層带 & 75 & 8.0 & 11000 \\
\hline 46 & 鶴川断層 & 30 & 7.3 & 80000 & 0.82 & - & - & 129 & 千股断虜 & 30 & 7.3 & 80000 \\
\hline 47 & 高山断層 & 18 & 6.9 & 13000 & 0.82 & $=$ & - & 130 & 淡路島北部断層帯 & 23 & 7.1 & 1300 \\
\hline$\frac{41}{48}$ & 神縄－国府津・松田断層带 & 25 & 7.2 & 23000 & 0.99 & -4000 & $\mathrm{a}$ & 131 & 虫典構造線淡路島南縁断層带 & 45 & 7.6 & 960 \\
\hline 49 & 曽根丘陵断層带 & 15 & 6.8 & 6500 & 0.67 & - & - & 132 & 長尾断層帯 & 20 & 7.0 & 14000 \\
\hline 50 & 富士川河口断層带 & 20 & 7.0 & 690 & 0.78 & 1854 & $\mathbf{a}$ & 133 & 江畑断層带 & 23 & 7.1 & 710000 \\
\hline 51 & 完荒川断層带 & 20 & 7.0 & 40000 & 0.39 & - & - & 134 & 中央構造線四国断層帯 & 165 & 8.5 & 15000 \\
\hline 52 & 丹那断層带 & 30 & 7.3 & 1200 & 1.50 & 1930 & $\mathrm{a}$ & 135 & 上町断層带 & 44 & 7.6 & 19000 \\
\hline 53 & 鮎喰川断層 & 30 & 7.3 & 800000 & 0.82 & - & $=$ & 136 & 黒菱山断層带 & 20 & 7.0 & 7300 \\
\hline 54 & 行当岬断層 & 15 & 6.8 & 1800 & 0.47 & $=$ & - & 137 & 猫又山断層 & 15 & 6.8 & 5900 \\
\hline 55 & 白馬断層 & 22 & 7.1 & 16000 & 0.97 & 1714 & $\mathrm{a}$ & 138 & 㴰登海岸断層群 & 15 & 6.8 & 16000 \\
\hline 56 & 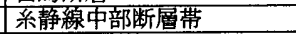 & 112 & 8.2 & 13000 & 0.98 & 841 & $a$ & 139 & 意知晹断層带 & 27 & 7.2 & 10000 \\
\hline 57 & 常念岳断層 & 24 & 7.1 & 15000 & 0.82 & - & - & 140 & 全沢平野車縁断層带 & 25 & 7.2 & 3800 \\
\hline 58 & 牛首断層 & 52 & 7.7 & 2000 & 0.82 & - & - & 141 & 上林川断層 & 25 & 7.2 & 15000 \\
\hline 59 & 跡洒川断層带 & 61 & 7.8 & 2500 & 0.34 & 1858 & $\mathrm{a}$ & 142 & 山田断膚 & 27 & 7.2 & 8700 \\
\hline 60 & 古川断層帯 & 30 & 7.3 & 80000 & 0.82 & - & - & 143 & 腙断層 & 30 & 7.3 & 8000 \\
\hline 61 & 国附断層带 & 20 & 7.0 & 1300 & 0.82 & $=$ & - & 144 & 京都西山断層群 & 30 & 7.3 & 12000 \\
\hline 62 & 高山断層带 & 45 & 7.6 & 5800 & 0.20 & - & - & 145 & 垗父断盧带 & 20 & 7.0 & 6700 \\
\hline 63 & 無数河断層带 & 18 & 6.9 & 13000 & 0.82 & $=$ & - & 146 & 山崎断層带 & 87 & 8.1 & 40000 \\
\hline 64 & 口有道断層带 & 19 & 7.0 & 13000 & 0.82 & - & - & \begin{tabular}{|l|l|}
147 \\
\end{tabular} & 那岐山断層 & 27 & 7.2 & 7700 \\
\hline 65 & \begin{tabular}{|l} 
\\
\end{tabular} & 22 & 7.1 & 14000 & 0.82 & - & - & \begin{tabular}{|l|}
148 \\
\end{tabular} & 窔道断層带 & 15 & 6.8 & 59000 \\
\hline 66 & \begin{tabular}{|l|} 
伊那断層带 \\
\end{tabular} & 16 & 6.8 & 8200 & 0.94 & - & $=$ & 149 & 上根断層 & 16 & 6.8 & 6100 \\
\hline 67 & 奈良井断層带 & 23 & 7.1 & 1400 & 0.82 & - & - & 150 & 五日市断層 & 20 & 7.0 & 6700 \\
\hline 68 & 境峠一神谷断層带 & 35 & 7.4 & 4000 & 0.94 & - & $=$ & 151 & 岩国断層带 & 50 & 7.7 & 10000 \\
\hline 69 & 伊那谷断層带 & 68 & 7.9 & 52000 & 0.99 & -3000 & $\mathrm{a}$ & 152 & 硰条断層 & 15 & 6.8 & 590000 \\
\hline 70 & 堸戈山断層 & 16 & 6.8 & 6100 & 0.82 & - & - & 153 & 䊩川断層 & 20 & 7.0 & 8500 \\
\hline 71 & 下伊那竜西断層带 & 15 & 6.8 & 2500 & 0.57 & - & - & 154 & 福智山断層 & 16 & 6.8 & 18000 \\
\hline$\frac{11}{72}$ & 中央構造線赤石西断層带 & 52 & 7.7 & 37000 & 0.20 & 715 & $\mathrm{a}$ & 155 & 西山断層带 & 29 & 7.3 & 110000 \\
\hline 73 & 清内路断層 & 44 & 7.6 & 19000 & 0.85 & - & - & 156 & 整固断層系 & 19 & 6.9 & 49000 \\
\hline 74 & 条曾玔断層群 & 45 & 7.6 & 9600 & 0.82 & - & - & 157 & 別府－方年山断層带 & 60 & 7.8 & 110000 \\
\hline 75 & 阿寺断層帯 & 62 & 7.8 & 2000 & 0.65 & 1586 & $a$ & 158 & 示縄断層帯 & 26 & 7.2 & 9200 \\
\hline 76 & 久野川断層带 & 17 & 6.9 & 6300 & 0.82 & - & - & 159 & 布田川断層带 & 24 & 7.1 & 7300 \\
\hline 77 & 佐見断層 & 26 & 7.2 & 7500 & 0.82 & - & - & 160 & 雲仙地溝断層群 & 17 & 6.9 & 5900 \\
\hline 78 & 赤河断層 & 18 & 6.9 & 6400 & 0.82 & - & - & 161 & 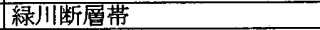 & 27 & 7.2 & 25000 \\
\hline 79 & 屏風山断層带 & 59 & 7.8 & 11000 & 0.82 & - & - & 162 & 日奈久断層带 & 60 & 7.8 & 11000 \\
\hline 80 & 恵那山断層 & 31 & 7.3 & 8100 & 0.82 & - & - & 163 & 出水断層带 & 22 & 7.1 & 23000 \\
\hline 81 & \begin{tabular}{|l|} 
猿投山断層带 \\
\end{tabular} & 43 & 7.6 & 10000 & 0.67 & -4850 & b & 164 & 蔍留盅浮菄縁断層带 & 17 & 6.9 & 6300 \\
\hline 82 & 笠原断層 & 17 & 6.9 & 13000 & 0.82 & - & - & 165 & 簏罗島湾西縁断層 & 20 & 7.0 & 670000 \\
\hline 83 & 座岡断層 & 20 & 7.0 & 13000 & 0.82 & 715 & - & & & & & \\
\hline
\end{tabular}

注）前回の地震発生年が負の值になっているものは紀完前を表す。また「一」は前回の地震発生年を特定できなかったもの

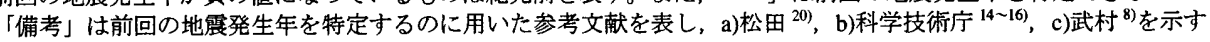




\section{(2)地震の規模}

表 3 で示した地震の規模そのものとする。

(3)発生周期の平均値とばらつき

一回の地震でずれる距離 $d(\mathrm{~m})$ を(6)式から評価し，それを平均変位 速度 $s_{R}$ (m/年)で除することによって評価する。平均変位速度は, 表 3 で示した地震の震源に近い断層の值を用いて，(2)の内陸活断層の 場合と同じ手法で評価した。

(4)前回の地震発生年

表 3 で示した地震が発生した年とする。

以上の手法に従い設定した震源データ位置を図 7 に, また, 諸元 を表 3 に示す。

表 3 活断層と関連しない大規模な地殼内地震の震源デー夕諸元

\begin{tabular}{|c|c|c|c|c|c|}
\hline \multirow{2}{*}{$\begin{array}{l}\text { 震源 } \\
\text { 番号 }\end{array}$} & \multirow[b]{2}{*}{ 地震名称 } & \multirow{2}{*}{$\begin{array}{c}\text { 規模 } \\
\mathbf{M}\end{array}$} & \multicolumn{2}{|c|}{ 発生周期 } & \multirow{2}{*}{$\begin{array}{c}\text { 前回の } \\
\text { 地震発生年 } \\
\text { 西暦(年) }\end{array}$} \\
\hline & & & $\begin{array}{c}\begin{array}{c}\text { 平均值 } \\
\text { (年) }\end{array} \\
\end{array}$ & $\begin{array}{l}\text { 変動 } \\
\text { 倸数 }\end{array}$ & \\
\hline $\mathrm{Pl}$ & 1900 年宫城県北部 & 7.0 & 17000 & 0.82 & 1900 \\
\hline $\mathrm{P} 2$ & 1984 年長野県西部 & 6.8 & 1300 & 0.82 & 1984 \\
\hline P3 & 1961 年北美濃 & 7.0 & 87000 & 0.82 & 1961 \\
\hline P4 & 1945 年三河 & 6.8 & 20000 & 0.23 & 1945 \\
\hline $\mathrm{P} 5$ & 1925 年北但馬 & 6.8 & 13000 & 0.82 & 1925 \\
\hline P6 & 1943 年鳥取 & 7.2 & 23000 & 0.82 & 1943 \\
\hline
\end{tabular}

\section{（4）大規模な海溝付近の地震の震源データ}

日本の太平洋側は, ユーラシアプレートに太平洋プレートとフィ リピン海プレートが沈み込んでおり，その境界で特に大規模な地震 が頻発している。この海溝付近の地震の発生周期はプレートの移動 速度と関連があるが，非地震性の滑りもあるため必ずしも単純では ない。これまでに，地震の発生周期を評価する方法として，比較的 規模の大きい地震のみを取り出しその発生間隔を統計処理する方法 19,22)や過去の地震による累積すべり量から評価する方法 ${ }^{23}$ 等, さまざ まな方法によって発生周期を評価する試みがなされている。ここで は，シナリオ地震用の震源データとして評価するために地震の規模 を特定しなくてはいけないことから，地震規模別に地震の発生年を

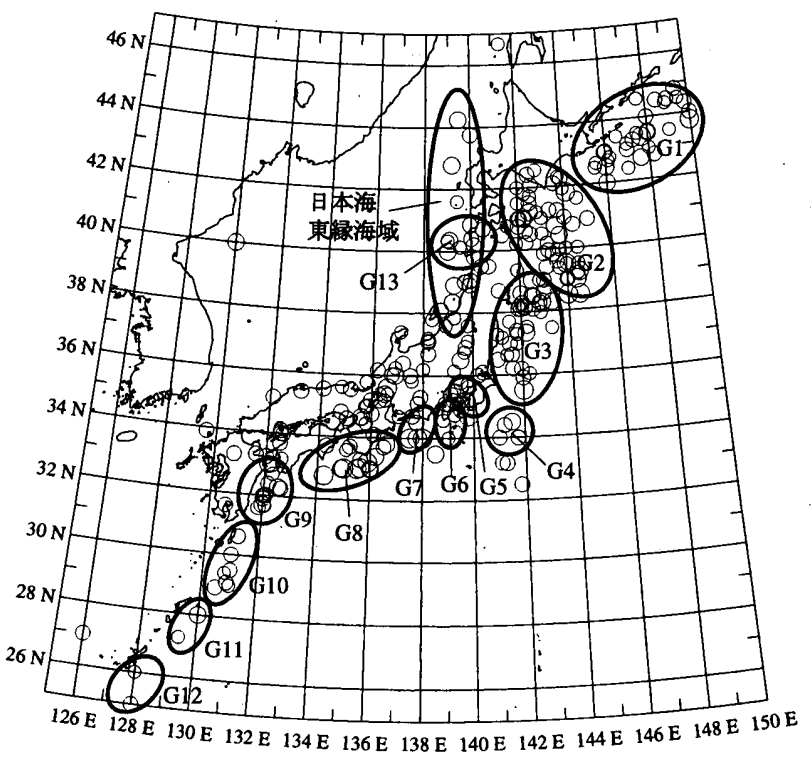

図 5 海溝付近の地震の発生周期を評価するための領域分け (O印は 599 年以降で $\mathrm{M} 6.8$ 以上の深さ $70 \mathrm{~km}$ 以浅の地震)
統計処理し，地震規模別の発生周期を評価することを試みる。

図 5 には, 文献 24 において最古の地震記録とされている 599 年以 降の M6.8 以上, 深さ $70 \mathrm{~km}$ 以浅の震源位置を示しているが, 海溝付 近の震源位置には疎密があることが分かる。これは, プレートの沈 み込み速度，非地震性滑りの割合の違い等さまざまな要因によるも のと考えられる。そこで, 密に地震が発生している領域(図 5 の楕円 形)をひとつのグループとして，そこに含まれる地震データから地震 規模別の発生周期を評価した。

地震規模のクラス分けは，(1)の中規模な地款内地震と同様に， マ グニチュード 0.5 刻みで M6.8〜M7.2(M7 クラス), M7.3〜M7.7(M7.5 クラス), M7.8 以上(M8 クラス)を基本としたが, 各領城での地震の 規模別発生状況を勘案して, 次項(1)に示すように個別に範囲を設定 した。

発生周期を評価するために使用した地震データは, 深さ $70 \mathrm{~km}$ 以浅 については M6.8 以上, 染さ $70 \mathrm{~km}$ 以深のやや梁発地震に対しては比 較的規模の大きな被害をもたらす深さ $70 \mathrm{~km} \sim 150 \mathrm{~km}$ で M7.5 以上 ${ }^{10)}$ を用いた。また, 対象期間は, 文献 25 において被害地震以外も含め て整備されている 1885 年以降を対象とし，1925 年までは文献 25 , それ以降は(1)と同じ気象庁データを用いた。ただし, 発生周期が長 く 1885 年以前の記録も用いる必要がある関東(図 5 の G5), 東海・南 海道(同 G7,G8)および南西諸島(同 G10〜12)については, それぞれ 1703 年元禄地震, 887 年南海地震および 1768 年琉球付近の地震以降 のデータも文献 24 に基づき用いている。

\section{(1)震源の位置}

震源は，地震規模別に，図 2(3)に示すような断層面として設定す る。断層面は，(3)の活断層と関連しない地震の震源データと同様に 地震規模から評価される断層面積と長さから決定し, 走向および傾 斜は, 設定した断層面の近傍で発生した過去の地震の断層パラメー タ ${ }^{12,26)}$ に基づき設定した。

断層面の位置は，基本的には，領域内で地震がまんべんなく発生 していると考えられる場合は過去の地震の震源域をカバーするよう に設定し，まばらに発生している場合には過去の地震の震源位置を 中心にした断層面を設定した。具体的には下記の通りである。

まず，過去に M8 クラスの地震が数回発生している G1,G2,G5,G7 および G8 では, 過去の地震の震源位置に基づき, 海溝に平行する形 で, M8 クラスの震源データの断層面を設定した。この際, ほとんど 同じ場所で同程度の規模の地震が複数回発生している場合は, ひと つの断層面とした（例えば, 1703 年元禄地震と 1923 年関東地震）。

また， G1〜G3 では，M7クラスの地震が各領域内でまんべんなく 発生していると考えられる。そこで, これらの領域では, 過去に発 生した M7 クラスの地震の震源域をできるだけカバーするように断 層面を設定し，それを $\mathrm{M} 7$ クラスの震源データとした。

G1 は, M8 クラス以外では, M7.6〜M7.7 のやや深発地震が 3 回, M6.8 M7.4 の浅発地震が 20 回以上発生していて, M7.5 M7.7 の浅 発地震は発生していない。そこで, M6.8〜M7.4 までの浅発地震を M7 クラスとして上述のように震源データを設定し, M7.6〜M7.7 の やや樑発地震に対しては過去に発生した地震の震源位置を中心にし た断層面を震源データとして設定した。

G2 は, M7 および M8 クラス以外では M7.5クラスが数回だけ発生 しており，G2 内でまんべんなく発生しているとは言い難いので，過 
去の地震の震源位置を中心にした断層面を設定した。

G3 における過去の地震の最大規模は M7.5 クラスであるが，その 震源位置は, 東経 142 度線上と宮城県沖の東経 143 度付近に集約で きると考えられる。そこで, G3 における M7.5 クラスの震源データ は, 東経 142 度線上と宮城県沖の東経 143 度付近に設定した。

G4 は, M7.0〜M7.5 の地震が密に発生しているので, ひとつの断 層面として設定した。

G5 は, M8 クラス以外ではM7クラスの地震しか発生していない。 そこで, M7 クラスの震源データは過去の震源位置に基づき, 相模卜 ラフに沿う形で 3 個, 1855 年江戸地震が発生した地点にひとつの断 層面を設定した。

G6 では，1880 年代および 1970 年代にそれぞれ 2 回ずつ, M7 ク ラスの地震が発生している。1 880 年代は伊豆半島沖, 1970 年代は伊 豆半島付近と場所が離れているので, それぞれの地震の震源位置に 断層面を設定した。

G7 および G8 は, M8 クラス以外では M7 クラスの地震があわせて 数回まばらに発生しているに過ぎない。そこで, M7 クラスの震源 データとして過去の地震の震源位置を中心にした断層面を設定した。

G9 では M6.8 以上の地震が 10 回発生している。やや深発地震であ る 1909 年宫崎県西部地震(M7.6)も，この付近のプレートの沈み込み に関連するものとして取り扱い, 1968 年日向灘地震(M7.5)とあわせ て M7.5クラスの地震とした。それ以外は全て日向灘で発生した M7 クラスである。そこで, M7.5 クラスは過去の地震の震源位置を中心 にした断層面, M7 クラスは過去に発生した震源域をできるだけカ バーする断層面を設定した。

G10〜G12 では, 領域の大きさに比べて地震の発生数が少なく, 領 域内でまんべんなく地震が発生しているとは言い難い。そこで, 過 去の地震の震源位置を中心にした断層面を設定した。

(2)地震の規模

海溝付近ではさまさまな規模の地震が発生するが, シナリオ地震 用の震源データとしては, 特定の値を設定する必要がある。そこで, 前項(1)で示した地震規模の範囲に対して, 過去の地震のマグニ チュードの平均値を代表マグニチュードとして設定した。

(3)発生周期の平均値とばらつき

地震の発生年を調べてみると，地震の発生には時間的な疎密があ ることがうかがえる。すなわち，立て続けにいくつかの地震が発生 したあと，しばらく地震活動が少ない時期があり，また再び活動が 活発になる，ということを繰り返していることが読み取れる。そこ で,ここでは, 図 6 の概念図が示すように, 活動が活発な時期(以下, 地震活動期と称する)における地震の発生を一塊として確率的に取

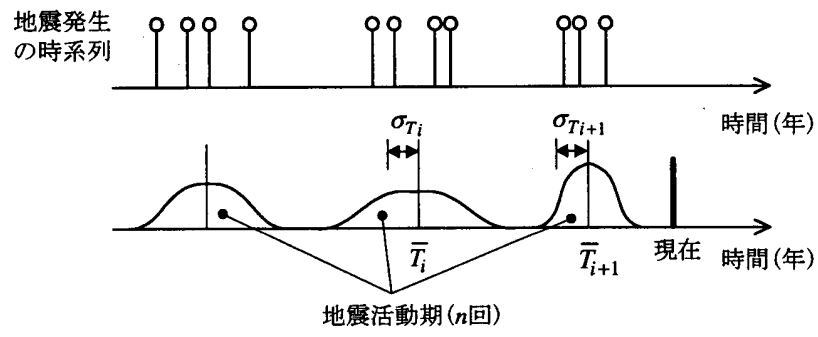

$\bar{T}_{i}, \sigma_{T i}$ : 地震活動期 $i$ 地震発生時刻 $T_{i}$ の平均値と標淮偏差

図 6 海溝付近の地震の発生周期の考え力
り扱い，地震活動期の間隔を統計処理することによって，発生周期 を評価することにする。

地震活動期 $i$ に扔いて発生した地震の発生時刻 $T_{i}$ を確率変数とし

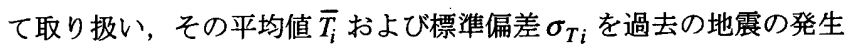
年から評価する。地震活動期における地震の発生時刻が確率変数で あるので, 地震活動期 $i$ から $i+1$ までの発生間隔 $T_{0, i}$ も確率变数とな り, その平均值 $\bar{T}_{0, i}$ およびその標準偏差 $\sigma_{T_{0, i}}$ は次式で評価される。

$\bar{T}_{0, i}=\bar{T}_{i+1}-\bar{T}_{i}, \quad \sigma_{T_{0, i}}=\sqrt{\sigma_{T_{i+1}}{ }^{2}+\sigma_{T_{i}}{ }^{2}}$

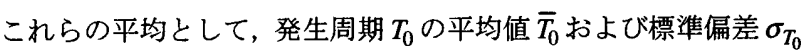
が次式で評価される。

$$
\bar{T}_{0}=\sum_{i}^{n-1} \bar{T}_{0, i} /(n-1), \quad \sigma_{T_{0}}=\sqrt{\sum_{i}^{n-1}\left(\bar{T}_{0, i}{ }^{2}+\sigma_{T_{0, i}}{ }^{2}\right) /(n-1)-\bar{T}_{0}{ }^{2}}
$$

ここで, $n$ は地震活動期の数である。なお, 最新の地震から現在 までの経過時間が発生周期の標準偏差よりも短く, かつ最新の地震 活動期における地震発生頻度が 1 回の地震活動期における平均発生 頻度に満たない場合は, 現在が地震活動期に相当していると考えた。 この場合には，それ以前の地震活動期の長さおよびばらつきの平均 的な值を, 現在の地震活動期の平均值および標準偏差として評価し た。また, 変動係数の下限值は活断層の場合と同様 0.2 とした。 (4)前回の地震発生年

図 6 に示すように, 地震は一塊となって発生すると仮定している ので, 前回の地震発生年は, 最新の地震活動期の平均值 $\bar{T}_{i}$ とする。

以上の手法に従い設定した大規模な海溝付近の地震の震源データ 位置を図 7 に，また，諸元を表 4 に示す。

表 4 の $v_{G}$ は, 一回の地震活動期における地震規模別平均発生頻度 を表す。これを地震規模別に設定した震源データの数 $N_{P}$ で除する ことにより，ひとつの震源データにおいて一回の地震活動期中に発

表 4 海溝付近の大規模な地震の震源データ諸元

\begin{tabular}{|c|c|c|c|c|c|c|c|c|}
\hline \multirow{2}{*}{$\begin{array}{l}\text { 領域 } \\
\text { 番号 }\end{array}$} & \multirow[b]{2}{*}{ 名称 } & \multirow{2}{*}{$\begin{array}{c}\text { 震源 } \\
\text { データ } \\
\text { の数 } N_{P}\end{array}$} & \multirow{2}{*}{$\begin{array}{c}\text { 評洒に } \\
\text { 用いた } \\
\text { Mの範囲 }\end{array}$} & \multirow{2}{*}{$\begin{array}{c}\text { 代表 } \\
\text { M }\end{array}$} & \multicolumn{2}{|c|}{ 発生周期 } & \multirow{2}{*}{$\begin{array}{l}\text { 前回の地 } \\
\text { 震発生年 } \\
\text { 西暦(年) }\end{array}$} & \multirow[b]{2}{*}{$\begin{array}{l}v_{G} \\
\text { (回) }\end{array}$} \\
\hline & & & & & $\begin{array}{c}\text { 平均値 } \\
\text { (年) }\end{array}$ & $\begin{array}{l}\text { 変動 } \\
\text { 係数 }\end{array}$ & & \\
\hline \multirow{3}{*}{ G1 } & \multirow{3}{*}{$\begin{array}{l}\text { 北海道 } \\
\text { 東方沖 }\end{array}$} & 507 & $78 \approx 81$ & $8.0 \%$ & 51 & 0.39 & 1964 & 2.5 \\
\hline & & 2 & $7.6 \sim 7.7$ & 7.7 & 51 & 0.20 & 1967 & 1.5 \\
\hline & & 22 & $6.8 \sim 7.4$ & 7.1 & 59 & 0.26 & 1974 & 11.5 \\
\hline \multirow{3}{*}{ G2 } & \multirow{3}{*}{$\begin{array}{c}\text { 三陸 } \\
\text { はるか沖 }\end{array}$} & 4 & $7.9 \sim 8.5$ & 8.2 & 55 & 0.26 & 1951 & 2.0 \\
\hline & & Th 5 , & $73 \sim 76$ & 75 & 48 & 0.58 & 1923 & 2.0 \\
\hline & & 31 & 6872 & 70 & 32 & 038 & 1966 & 117 \\
\hline \multirow{2}{*}{ G3 } & \multirow{2}{*}{$\begin{array}{l}\text { 福島県 } \\
\text { 禺方沖 }\end{array}$} & 5 & $7.3 \sim 7.7$ & 7.5 & 41 & 0.32 & 1978 & 2.7 \\
\hline & & 20 & $6.8 \sim 7.2$ & 7.0 & 27 & 0.34 & 1982 & 5.8 \\
\hline G4 & 房総沖 & 1 & $7.0 \sim 7.5$ & 7.3 & 43 & 0.20 & 1954 & 2.0 \\
\hline \multirow{2}{*}{ G5 } & \multirow{2}{*}{ 関東 } & 1 & $7.9 \sim 8.1$ & 8.0 & 220 & $0.42^{41}$ & 1923 & 1.0 \\
\hline & & 4 & $6.8 \sim 7.3$ & 7.0 & 70 & 0.42 & 1923 & 1.7 \\
\hline G6 & 伊豆 & 4 & $6.8 \sim 7.0$ & 7.0 & 88 & 0.20 & 1976 & 2.0 \\
\hline \multirow{2}{*}{ G7 } & \multirow{2}{*}{ 東海 } & 1 & $7.9 \sim 8.4$ & 8.3 & 253 & 0.48 & 1854 & 1.0 \\
\hline & & 1 & $7.0 \sim 7.3$ & 7.2 & 169 & 0.48 & 1855 & 1.0 \\
\hline \multirow{3}{*}{ G8 } & \multirow{3}{*}{ 南海道 } & 2 & $8.2 \sim 8.4$ & 8.4 & 242 & 0.30 & 1854 & 1.0 \\
\hline & & 3 & $7.4 \sim 8.0$ & 7.9 & 179 & 0.64 & 1946 & 1.3 \\
\hline & & 3 & $6.8 \sim 7.0$ & 7.0 & 154 & 0.20 & 1943 & 1.5 \\
\hline \multirow{2}{*}{ G9 } & \multirow[b]{2}{*}{ 日向灘 } & 1 & $7.5 \sim 7.6$ & 7.6 & 58 & $0.41^{* 1}$ & 1968 & 1.0 \\
\hline & & 3 & $6.8 \sim 7.2$ & 7.0 & 16 & 0.41 & 1984 & 1.3 \\
\hline G10 & 種子島近海 & 5 & $6.8 \sim 7.4$ & 7.1 & $152^{* 2}$ & $0.20^{* 2}$ & 1919 & 7.0 \\
\hline \multirow{2}{*}{ G11 } & \multirow{2}{*}{ 奄美諸島 } & 1 & 8.0 & 8.0 & $152^{* 2}$ & $0.20^{52}$ & 1911 & 1.0 \\
\hline & & 2 & $6.9 \sim 7.5$ & 7.2 & $152^{* 2}$ & $0.20^{* 2}$ & 1920 & 2.0 \\
\hline 12 & 沖縄島 & 2 & $6.8 \sim 7.4$ & 7.1 & 152 & 0.20 & 1921 & 1.5 \\
\hline
\end{tabular}

$v_{G}: 1$ 回の地震活動期における地震規模別平均発生頻度

網掛けは，現在，地震活動期中であることを示す。

*1 : 同じ領域の代表 M7.0における変動係数と同じにした。

*2：同時期に地震が発生している領域 G12 と同じにした。 
生する地震の平均頻度が評価できる。例えば，北海道東方沖の領域 (G1)では, 1 回の地震活動期に代表 M7.1 の地震が平均 11.5 回発生し ているが，22 個の震源データを設定したので，ひとつの震源データ の発生頻度は 1 回の地震活動期中において 11.5/22=0.52 回となる。 すなわち, この領域で設定した震源データは概ね 2 回の地震活動期 で平均. 1 回の M7.1 程度の地震が発生するということになる。

なお，現在，その領域が地震活動期に入っており，現在すでにい くつかの地震が発生している場合は, “地震規模別発生頻度からすで に発生している地震の個数を除いて評価した。また, 関東(G5)の M8.0 級のように過去に 2 回しか地震が記録されておらず発生周期のばら つきを評価することができないもの，あるいは種子島近海(G10)のよ うに，歴史地震データが乏しく発生周期の平均值すら評価できない ものについては，地震の発生の仕方が似ていると考えられる同じ領 域あるいは近くの領域での值と同じにした。

\section{（5）日本海東縁海域の大規模な地震の震源データ}

日本海東縁海域は, 沈み込みプレートが形成される初期の段階で あり ${ }^{27)}$ ，ここで発生する地震は必ずしもプレート境界地震とは言え ないが, これまでに M7.5 以上の被害地震がいくつか発生しているの で, この海域についてもシナリオ地震用の震源データを設定する必 要がある。男鹿半島沖付近(図 5 の G13)では，空間的には密に，時間 的には疎密をもって地震が発生している。そこで, (4)の海溝付近の 地震と同じ手法で震源位置, 発生周期等を設定する。一方, それ以 外については, この海域での海底断層の規模や形態が内陸の活断層 と大きく異ならないことが指摘されていることから ${ }^{27)}$, (3)の地殼内 地震による評価と同じ手法で，比較的規模の大きな被害を伴った過 去の地震の震源位置を中心とした断層面を設定する。ただし，その 際, 発生周期の平均値を評価するための平均変位速度 $s_{R}$ ( $\mathrm{m} /$ 年)は, GPS で観測された佐渡島付近の地款水平変位ベクトル ${ }^{28)}$ から $s_{R}=0.01(\mathrm{~m} /$ 年) とした。

使用した地震データは(4)の海溝付近の地震と同じものを用いた。 ただし, 日本海東縁海域は, 太平洋側に比べ地震の発生周期が長い ため, 1694 年能代地方の地震以降のデータを用いた。

震源データの位置を図 7 に，また，諸元を表 5 に示す。

表 5 日本海東縁海域の大規模な地震の震源デー夕諸元 (a) 海溝付近の地震と同様な手法で評価したもの

\begin{tabular}{|c|c|c|c|c|c|c|c|c|}
\hline 領域 & & 震源 & 評価に & 代表 & 発生 & & 前回の地 & \\
\hline 番号 & 名称 & $\begin{array}{c}\text { データ } \\
\text { の数 } N_{P}\end{array}$ & $\begin{array}{c}\text { 用いた } \\
\mathbf{M} \text { の範囲 }\end{array}$ & M & $\begin{array}{l}\text { 平均値 } \\
\text { (年) }\end{array}$ & $\begin{array}{l}\text { 変動 } \\
\text { 係数 }\end{array}$ & $\begin{array}{l}\text { 震発生年 } \\
\text { 西暦(年) }\end{array}$ & \\
\hline G13 & 男鹿半島付近 & 5 & $6.8 \sim 7.0$ & 7.0 & 126 & 0.27 & 1952 & 1 \\
\hline
\end{tabular}

$v_{G}: 1$ 回の地震活動期における地震規模別平均発生頻度

(b) 過去の被害地震の震源位置に基づき設定したもの

\begin{tabular}{|c|c|c|c|c|c|}
\hline \multirow[b]{2}{*}{$\begin{array}{l}\text { 震源 } \\
\text { 番号 }\end{array}$} & \multirow{2}{*}{$\begin{array}{c}\text { 地䟴名称あるいは } \\
\text { 地震発生地域 }\end{array}$} & \multirow[b]{2}{*}{$\begin{array}{c}\text { 規模 } \\
\text { M }\end{array}$} & \multicolumn{2}{|c|}{ 発生周期 } & \multirow{2}{*}{$\begin{array}{c}\text { 前回の } \\
\text { 地震発生年 } \\
\text { 西暦(年) }\end{array}$} \\
\hline & & & $\begin{array}{c}\text { 平均値 } \\
\text { (年) }\end{array}$ & $\begin{array}{l}\text { 変動 } \\
\text { 係数 }\end{array}$ & \\
\hline P7 & 1940 年積丹半島沖 & 7.5 & 316 & 0.20 & 1940 \\
\hline P8 & 1993 年北海道南西沖 & 7.8 & 479 & 0.20 & 1993 \\
\hline P9 & 1983 年日本海中部(余震) & 7.1 & 182 & 0.20 & 1983 \\
\hline P10 & 1983 年日本海中部 & 7.7 & 417 & 0.20 & 1983 \\
\hline P11 & 1833 年羽前 $\cdot$ 羽後 $\cdot$ 越後 & 7.5 & 316 & 0.20 & 1833 \\
\hline P12 & 1964 年新潟 & 7.5 & 316 & 0.20 & 1964 \\
\hline
\end{tabular}

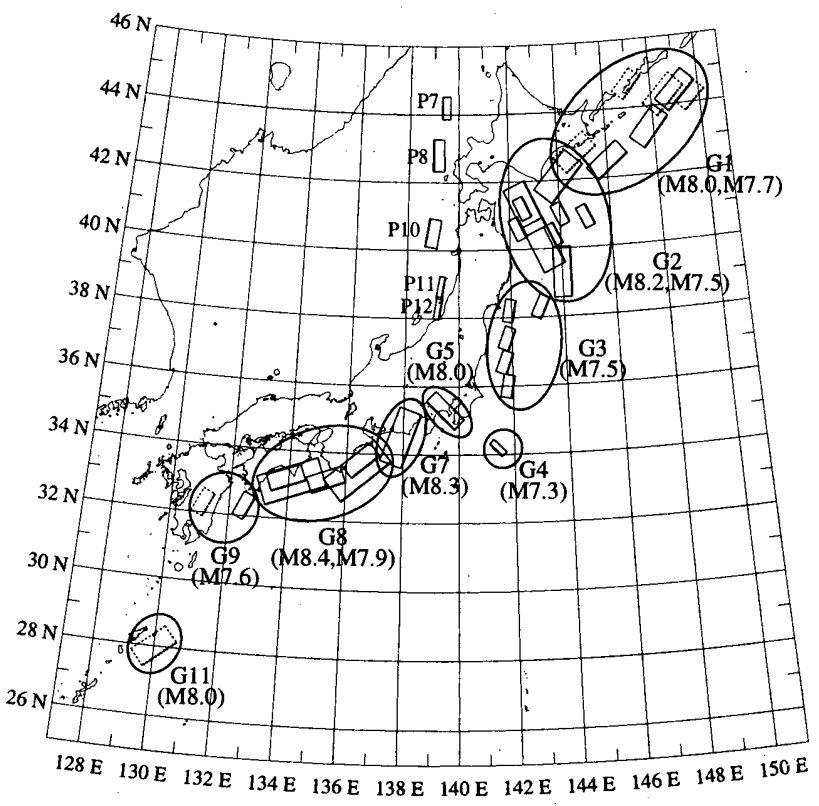

(a) M7.3 以上

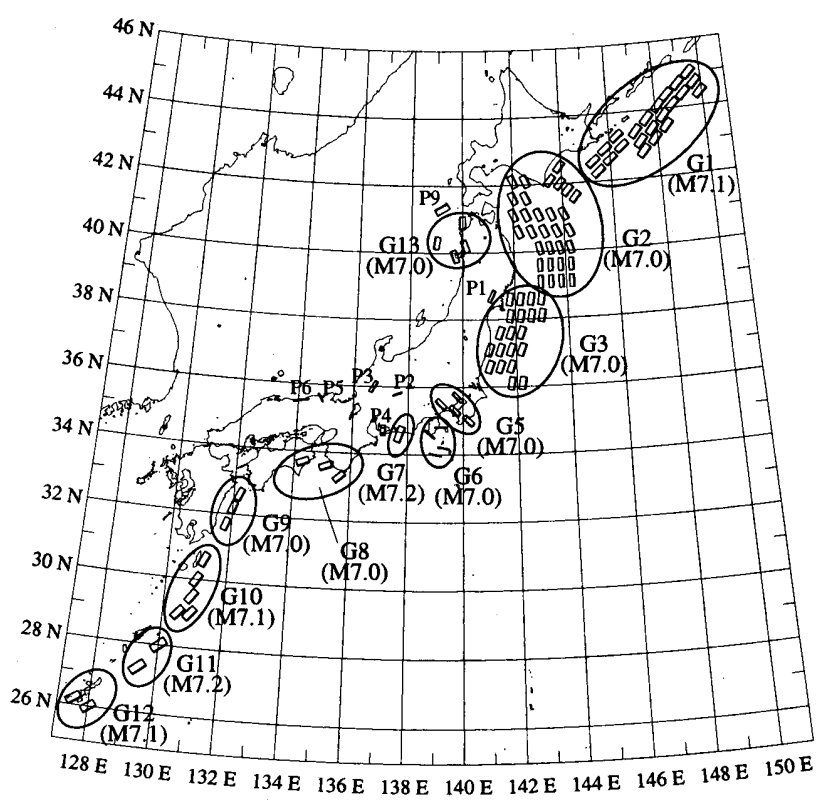

(b) M7.2 以下

図 7 活断層と関連しない大規模な地殼内地震, 海溝付近の地震 および日本海東縁海域の地震の震源データの位置 (点線の震源データはやや深発地震であることを示す)

\section{3. 地震発生確率および最大地動加速度の評価方法}

\section{1 地震発生確率の評価方法}

地表面に断層が表れない中規模な内陸型地震や，前回の地震発生 年が不明な活断層については，地震はランダムに発生するものとし てポアソン過程に従って発生確率を評価する。震源データの発生周 期を $T_{O}$ (確定値)とすると, 今後 $\Delta T$ 年間に地震が発生する確率は次 式で表される。

$$
P(\Delta T)=1-\exp \left(-\Delta T / T_{0}\right)
$$

一方, その震源が直前に活動した時期が明らかなものについては, 発生周期を確率変数として取り扱い，発生確率を評価する。文献 19 によると, 最新の地震から現在までの期間が地震の発生周期よりも 
長くなると，発生周期の確率分布型の仮定の違いによって発生確率 の評価結果は大きく異なる。ここでは, 発生確率の頭打ちが起こら ない Weibull 分布に従うと仮定する。Weibull 分布の確率密度関数は 次式で表される ${ }^{15,19)}$ 。

$$
f(t)=\alpha \beta t^{\beta-1} \exp \left(-\alpha t^{\beta}\right)
$$

ここで， $\alpha$ および $\beta$ はパラメータで, 発生周期の平均值と標準偏 差から評価できる。これより，「前回の地震から現在まで地震が発 生していないという条件付き累積確率として, 今後 $\Delta T$ 年間に地震 が発生する確率が次式で評価できる ${ }^{15.19) 。 ~}$

$$
P\left(\Delta T, T_{P}\right)=1-\exp \left[-\alpha\left\{\left(T_{P}+\Delta T\right)^{\beta}-T_{P}^{\beta}\right\}\right]
$$

ここで， $T_{P}$ は前回の地震から現在までの経過年数である。

ただし, 海溝付近の地震のように地震活動期を設定して発生周期 を評価したものについては, 一回の地震活動期における地震規模別 平均発生頻度 $v_{G}$ を考慮して今後 $\Delta T$ 年間に地震が発生する確率を 評価する。すなわち, ひとつの震源データにおいて一回の地震活動 期に発生する地震の規模別頻度は $v_{G} / N_{P}$ であるので, 一回も地震 が発生しない確率は $\left\{1-P\left(\Delta T, T_{P}\right)\right\}^{v_{G} / N_{P}}$ で評価できる。ここで, $N_{P}$ は各領域で設定した地震規模別震源データの数である。この確率を 1 から引くことにより, 今後 $\Delta T$ 年間に, ひとつの震源データにおいて 一回の地震活動期に一回以上の地震が発生する確率が評価できる。

$$
P_{G}\left(\Delta T, T_{P}\right)=1-\left\{1-P\left(\Delta T, T_{P}\right)\right\}^{v_{G} / N_{P}}
$$

\section{2 最大地動加速度の評価方法}

福島・田中による距離減衰式 ${ }^{29)}$ を用いて最大地動加速度 PGA を評 価した。

$$
\operatorname{PGA}\left(\mathrm{cm} / \mathrm{s}^{2}\right)=10^{0.51 M-\log \left(R+0.006 \cdot 10^{0.51 M}\right)-0.0034 R+0.59}
$$

福島・田中式では, 評価地点と震源との距離 $R(\mathrm{~km})$ は断層面への 最短距離である。地表面に断層が表れない中規模な地款内地震の場 合は地震がランダムに発生すると仮定する地震発生面, それ以外に ついては想定した断層面に対して評価地点からの最短距離を計算し， それを $R$ とした。

\section{4. 評価例}

2 章で整備した震源データの中から, 各評価地点におけるシナリオ 地震を選定し，シナリオ地震による地震危険度を評価する。

シナリオ地震の選定にあたっては，まず，「現実的に起こりうる もの」を選定するため, 各震源データの現在における発生確率を 3.1 節で示した方法により評価し, 震源データ作成に用いた活断層およ び歴史地震の精度や収録期間あるいは建物の供用期間を考虑して, 現実問題として有意であると考えられる発生確率を有するものを選 定する。「有意であると考えられる発生確率」は, 用途や条件によっ て異なるものになると考えられるが,ここでは，文献 30 に基づき， 50 年発生確率が $2 \%$ 以上震源データを対象とした。

次に, 有意な発生確率を有する震源データの中から, 3.2 節で示し た方法で評価された PGA が大きいもののうち, そのいくつかをシナ リオ地震として選定する。なお， シナリオ地震としては，本来地震 による被害が最大となるものを選定すべきであるが，ここでは便宜 的に地震動の大きさと地震による被害の規模は比例すると仮定した。

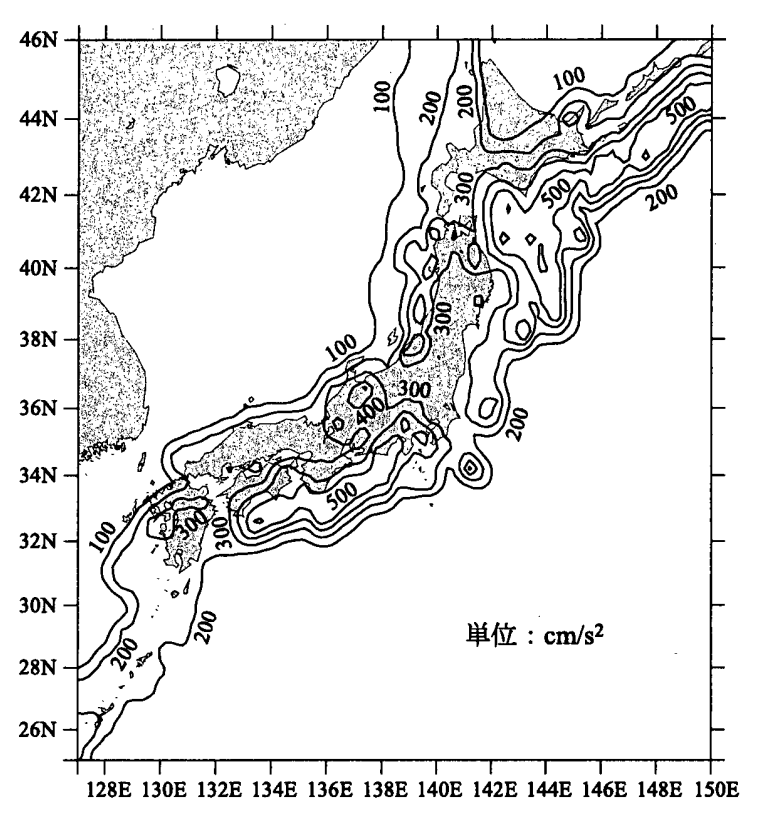

図 8 シナリオ地震による日本全国の最大地動加速度分布図 (2000 年 1 月現在における 50 年発生確率が $2 \%$ 以上)

図 8 に 50 年発生確率が $2 \%$ 以上のシナリオ地震による日本全国の PGA 分布図を示す。海溝付近の地震が有意な太平洋沿岸で $500 \mathrm{~cm} / \mathrm{s}^{2}$ 以上の PGA となっている他, 富山県付近および日本海沿岸でも $400 \mathrm{~cm} / \mathrm{s}^{2}$ 以上の PGA となっている。これは, 牛首断層(M7.7)および 日本海東緣海域の地震によるものである。

一方, 図 9 に示す比較的近傍に位置する 3 地点に対して, 上記と 同じ 50 年発生確率が $2 \%$ 上の基準で選定したシナリオ地震のうち, PGA の大きさが上位 2 つを表 6 に示した。表中，「直下」，「近傍」 はそれぞれ評価地点を含むメッシュ(地表面に断層が表れない中規 模な地款内地震の震源データ)およびその隣のメッシュを表してい る。よって, 同じ「直下」でも評価地点によって震源データは異な る。また, 「海溝付近」は領域 G5 の M8 クラスの地震(関東地震の 再来)の震源データを表している。これら 3 地点は, いずれも同じ地 震域(図 1 のS10)内に位置しているため, 表 6 に示されるように, 直 下 M6.0による PGA は同じ值になっている。これは, 同じ地震域内 であれば，評価地点がどこであれ直下地震による評価は同じになる ことを示している。ただし, 近傍 M6.0による PGA は上野と浦和市 では異なる值になっている。これは, 評価地点の位置により隣のメッ シュまでの距離が異なるためであり, 評価地点近傍で起こる中規模 な地款内地震の震源データをシナリオ地震として設定する場合には 注意する必要があることを示している。

次に, 複数の建物に対する全体の地震被害について検討した。上 述のように, ここでは, 地震被害の大きさは PGAの大きさに比例す ると仮定しているので, 全体の地震被害は PGA の総和として表され ることになる。表 6 では, PGA の総和を評価地点の数で割ったもの, すなわち, 評価した 3 地点の $\mathrm{PGA}$ の平均がもっとも大きくなる震源 データを「3 地点の平均」の欄に示している。それによると，3地点 全体で見た場合では, 海溝付近の震源データによる PGA の平均值が もっとも大きくなり, 中規模な地殸内地震 $\mathrm{M} 6.0$ が 2 番目となる。も し仮に, これら 3 地点を含む S10 の地震域全体を震源データとし, この領域内では地震が空間的にランダムに発生すると仮定すれば, 
中規模な地殸内地震の震源データによる PGAの平均值は各評価地点 と同じ $268 \mathrm{~cm} / \mathrm{s}^{2}$ となる。それに対して，中規模な地款内地震の震源 データをメッシュとして表すことにより，この震源データによる PGA の平均值は $217 \mathrm{~cm} / \mathrm{s}^{2}$ と小さくなり，比較的近傍に点在する複数 の評価地点に対して, 個々の地点では影響の大きい直下地震が全体 としては影響が小さくなる現象を表すことができている。

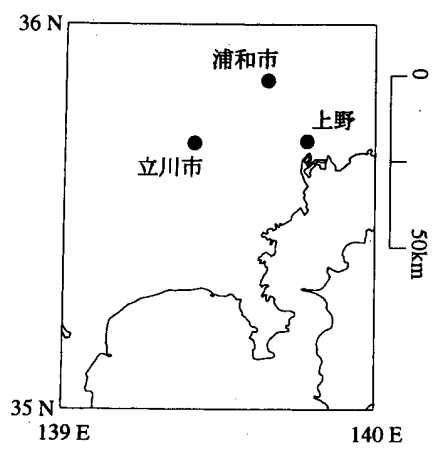

図 9 評価地点の位置

表 6 各地点において最大地動加速度が大きい震源データ $(2000$ 年 1 月現在における 50 年発生確率 $P(50)$ が $2 \%$ 以上)

\begin{tabular}{|c|c|c|c|}
\hline & & 1 位 & 2位 \\
\hline \multirow{3}{*}{$\begin{array}{l}\text { 上 } \\
\text { 野 }\end{array}$} & 種類 & 值下 M6.0 & 近傍 M6.0 \\
\hline & $\mathrm{PGA}\left(\mathrm{cm} / \mathrm{s}^{2}\right)$ & 268 & 258 \\
\hline & $P(50)$ & $4.1 \%$ & $4.1 \%$ \\
\hline \multirow{3}{*}{$\begin{array}{l}\text { 浦 } \\
\text { 和 } \\
\text { 市 }\end{array}$} & 種類 & 直下 M6.0 & 近傍 M6.0 \\
\hline & $\mathrm{PGA}\left(\mathrm{cm} / \mathrm{s}^{2}\right)$ & 268 & 245 \\
\hline & $P(50)$ & $4.1 \%$ & $4.1 \%$ \\
\hline \multirow{3}{*}{$\begin{array}{l}\text { 立 } \\
\text { 川 } \\
\text { 市 }\end{array}$} & 種類 & 海溝付近 M8.0 & 直下 M6.0 \\
\hline & $\mathrm{PGA}\left(\mathrm{cm} / \mathrm{s}^{2}\right)$ & 338 & 268 \\
\hline & $P(50)$ & $12 \%$ & $4.1 \%$ \\
\hline \multirow{3}{*}{$\begin{array}{l}3 \text { 地点 } \\
\text { の平均 }\end{array}$} & 種類 & 海溝付近 M8.0 & 中規模な地殼内地震 M6.0 \\
\hline & $\mathrm{PGA}\left(\mathrm{cm} / \mathrm{s}^{2}\right)$ & 278 & 217 \\
\hline & $P(50)$ & $12 \%$ & $4.1 \%$ \\
\hline
\end{tabular}

\section{5. まとめ}

日本全国を対象として，シナリオ地震となり得る震源データを整 備するとともに, シナリオ地震による地震危険度評価手法を提示し た。特に，地表面に断層として表れない地款内地震に対しても，そ の震源位置を特定する手法を示すことにより，活断層や沈み込みに よる地震と同様な取り扱いができる可能性を示した。さらに，地震 規模だけではなくその発生確率も同時に評価したことにより，シナ リオ地震の選定に対して，より有益な情報が付加された。

ただし，日本全国を対象として震源データを設定したため，デー タがそしい等の理由により，部分的にはかなり大胆な仮定をせざる を得ないところもあった。また，地表面に断層として表れない地殼 内地震に対するマグニチュードの与え方については，より合理的な 判断が下せるような, さらなる検討が必要であることも今後の課題 として残された。

\section{謝辞}

(株)篠塚研究所・中村孝明博士には本研究をまとめる動機つけりとご教示を， 大成建設(株)・吉村智昭氏からは貴重なご助言を，活断層データの整理にあ たっては大成建設(株)・中島崇裕氏のご協力をいただきました。また，匿名查
読氏には適切かつ貴重なコメントを頂戴いたしました。ここに感謝の意を評し ます。また, 1926 年以降の地震データとして, 気象庁震源データ((財)気象業 務支援センター発行)を用いました。

参考文献

1）森本祐司：金融と保険の融合について，IMES Discussion Paper No.99-J-13, 日本銀行金融研究所, 1999 年

2) Cornell, C.A. : Engineering Seismic Risk Analysis, Bull. Seism. Soc. Am., Vol.58, No.5, pp.1583-1606, 1968

3) Mualchin, L. : Development of the Caltrans Deterministic Fault and Earthquake Hazard map of California, Engineering Geology 42, pp.217-222, 1996

4) Anderson, J.G. : Benefits of Scenario Ground Motion Maps, Engineering Geology 48, pp.43-57, 1997

5) Kawasumi, H. : Measures of Earthquake Danger and Expectancy of Maximum Intensity Throughout Japan as Inferred from the Seismic Activity in Historical Times, Bulletin of the Earthquake Research Institute, Vol.29, pp.469-482, 1951

6) 亀田弘行, 石川裕, 奥村俊彦, 中島正人 : 確率論的想定地震の概念と応用, 土木学会論文集 No.577， I-41，pp.75-87，1997 年 10 月

7）安中正, 矢代晴実 : 大地震の発生サイクルを考慮した日本列島の地震危険 度解析モデル，第 10 回日本地震工学シンポジウム, $1, \mathrm{pp} .489-494,1998$ 年

8）武村雅之 : 日本列島における地殻内地震のスケーリング則一地祳断層の影

響および地震被害との関連一, 地震, 第 2 輯, 第 51 巻, pp.211-223，1998 年

9）渡辺基史, 佐藤俊明, 壇一男: 内陸地震の断層パラメータの相似則, 第 10 回日本地震工学シンポジウム, pp.583-588, 1998 年

10) 武村雅之, 加藤研一, 八代和彦: やや梁発地震および深発地震の発生地域,

頻度，被害歴，日本建築学会技術報告集，第 3 号，pp.269-274，1996 年

11) 萩原尊禮：日本列島の地震, 鹿島出版会, 1991 年

12）佐藤良輔：日本の地震断層パラメター・ハンドブック,鹿島出版会,1989 年

13) 活断層研究会 : 新編 日本の活断層, 東京大学出版会, 1990 年

14) 科学技術庁: 平成 7 年度 - 平成 8 年度 地震調查研究交付金成果報告会 予 稿集, 平成 9 年

15) 科学技術庁：第 2 回活断層調查成果報告会 予稿集, 平成 10 年

16) 科学技術庁：第 3 回活断層調查成果報告会 予稿集，平成 11 年

17）松田時彦：最大地震規模による日本列島の地震分帯図，地震研究所彙報， Vol.65, pp.289-319, 1990 年

18）松田時彦: 活断層から発生する地震の規模と周期について, 地震, 第 2 輯, 第 28 巻, pp.269-283，1975 年

19) 地震調查研究：(試案)長期的な地震発生確率の評価手法及びその適用例に つい, 地震調查研究推進本部 地震調查委員会 長期評価部会, 平成 10 年

20) 松田時彦: 陸上活断層の最新活動期の表，活断層研究，13, pp.1-13, 1995 年

21）奥村俊彦，石川裕，亀田弘行 : 活断層の活動履歷に関する情報を考慮した 地震危険度評価，土木学会第 2 回阪神・淡路大震災に関する学術講演会論 文集，pp.49-56，1997 年 1 月

22) Utsu, T. : Estimation of Parameters for Recurrence Models of Earthquakes, Bulletin of the Earthquake Research Institute, Vol.59, pp.53-66, 1984

23) Shimazaki, K. and Nakata, T. : Time-predictable Recurrence Model for Large Earthquakes, Geophysical Research Letters, Vol.7, No.4, pp.279-282, April 1980

24）宇佐美龍夫 : 新編日本被害地震総臨 增補改訂版 416-1995, 東京大学出版 会, 1996 年

25）宇津徳治：日本付近の M6.0 以上の地震および被害地震の表 : 1885 年〜 1980 年, 地震研究所彙報, Vol.57, pp.401-463，1982 年

26）弘田智樹，小野若菜，工藤一嘉：経験的グリーン関数法に基づく安政江 戸地震の震源推定と強震動評価，第 4 回都市直下地震災害シンポジウム, pp.435-438, 1999 年

27）岡村行信, 倉本真一，佐藤幹夫：日本海東縁海域の活構造およびその地 震との関係，地質調查所月報，第 49 巻，第 1 号，pp.1-18，1998 年

28）多田克：フォッサマグナ西縁はプレート境界か? (2), 日本地震学会講演 予稿集，No.2，B33，1996 年

29) Fukushima, Y. and Tanaka, T. : A New Attenuation Relation for Peak Horizontal Acceleration of Strong Earthquake Ground Motion in Japan, Shimizu Tech. Res. Bull., No.10, pp.1-11, March 1991

30) Frankel, A. : National Seismic-Hazard Maps, June 1996, U.S. Department of Interior, U.S. Geological Survey, 1996 